\title{
Improving the Skill of Recognizing Poetry Text Building Elements Through the Think Pair Style Cooperative Learning for Students Class VIII-A at SMP N 24 OKU
}

\author{
Salismiati $^{1 *}$, Missriani $^{2}$, Yessi Fitriani ${ }^{2}$ \\ ${ }^{1}$ SMP N 24 OKU, South of Sumatra, Indonesia \\ ${ }^{2}$ Universitas PGRI Palembang, Indonesia \\ ${ }^{*}$ Corresponding author. Email: salismiati8@gmail.com
}

\begin{abstract}
The goal of this study is to explain an increase in the ability to recognize the building blocks of poetry text by applying the Form Cooperative Learning Model Think Pair to Class VIII-A students at Class VIII-A at SMP N 24 OKU. Data collection techniques: (1) observation, (2) checking. The data analysis methodology shall be processed using the percentage formula. The results of this study show that there is an improvement in the ability to recognise the building blocks of poetry text through the cooperative learning model think pair share in Class VIII-A at SMP $\mathrm{N} 24 \mathrm{OKU}$ in each cycle can be clarified that the results obtained in action cycle 1 are 1610 with an average of 64,40. There were 11 students who completed the course with an average percentage of completeness of $44 \%$. There was an improvement in Cycle 2 where the findings reached a value of 1775 with an average of $71 \%$. Students who complete the course are 17 students with an overall percentage of completeness of 17 percent. Then the action cycle 3 increased again where the results obtained were 1855 with an average of 74,20. Students who complete the course are 23 students with an overall percentage of completeness of $92 \%$.
\end{abstract}

Keywords: Poetry Text, Building Elements, Cooperative Learning

\section{INTRODUCTION}

In essence, the purpose of literary learning is to develop the ability to appreciate literature, which means that after studying literature, students are supposed to be able to identify, understand, appreciate and appreciate literary works. It is like a mirror that shows a sign of progress in the life of a country.

In poetry learning activities, students are led to understand theories related to building blocks of poetry, such as themes, messages, poetry, expression, rhythm, word connotations, words with symbols, and imagination. Learning literature, particularly poetry, cannot be ignored, but it needs to be instilled in students so that students have a broad understanding and application of it, so that students have a positive attitude towards literature (poetry).

Poetry is a variety of literature whose vocabulary is bound up with the rhythm, dimension, rhythm and arrangement of lines and stanzas. In addition, poetry is also described as a poem or composition in a language that is carefully chosen and arranged in such a way as to increase people's knowledge of experiences and generate specific reactions by structuring sounds, rhythms and special meanings. Usually, poetry is used to express the author's thoughts and feelings by giving importance to the beauty of language.

According to Wardoyo [1], the elements found in the body of literary works are inherent elements. Every literary work, whether it be poetry, prose or drama, has a different inherent aspect. In addition, Wardoyo [1] argues that extrinsic elements are building blocks of poetry outside the manuscripts of poetry which influence the life of literary works as works of art.

Wardoyo [1] also points out that the structure of poetry is the building block of poetry, both language (physical structure) and substance that the poet aims to express with emotion and mental atmosphere (inner structure). In addition, Pradopo [2] argues that the structure of poetry is a systemic arrangement of elements in which there is a reciprocal and mutually deciding relationship between the elements. In addition, 
according to Waluyo [3], the structure of poetry is a focus and intensification in which there are elements of emotion and imagination.

Jabrohim [4] divides the elements of poetry into two, namely: (1) the type of elements which can be referred to as physical structures, including: diction; pengimajian; concrete words; figurative; rhythm and rhythm; as well as typography. (2) The content aspect can also be referred to as an inner structure consisting of themes; tone; feeling; and mandate.

Pradopo [2] states that poetry is a similarity of experience that is interpretive in a rhythmic/significant language. In addition, according to Kosasih [5], poetry is a type of literary work that uses the beautiful words of the literary work. In addition, Waluyo [3] argues that poetry is a literary work with a language that is compressed, condensed and provided a rhythm with a coherent sound and a collection of (imaginative) study words.

Based on the results of the preliminary data of the researcher, for two semesters the students of class VIIIA SMP Negeri $24 \mathrm{OKU}$ in teaching the content established the elements of the building blocks of the text of poetry, with a student average score of 57 . This means that they do not achieve the minimum critical completion (KKM) of 70 , since they still use the teaching and assignment process, so that they do not achieve the minimum critical completion (KKM) of 70 .

In order to harmonize the Indonesian language learning process for identifying the building blocks of poetry text, it is important to apply the Think Pair Share learning model so that the learning process can run efficiently and efficiently. One learning model that is known to be good and sufficient for learning how to recognize the building blocks of poetry text is the use of a think pair sharing type of cooperative learning model application.

The Type of Think Pair Sharing (TPS) Cooperative Learning Model is a type of co-operative learning designed to affect student interaction patterns. This TPS learning model was built from cooperative study and waiting time. It was first developed by Frang Lyman and colleagues [6] at the University of Maryland who said that TPS is an efficient way to shift the environment of class discussion patterns.

Roestiyah [7] states that the cooperative learning model is a learning model that positions students as subjects of learning (student oriented). With a democratic classroom environment that allows each other more opportunities to inspire students to the fullest. The role of teachers as facilitators, moderators, organizers and mediators in cooperative learning is clear.
Kasimmudin [8] describes some of the benefits of introducing a peer-reviewed form of cooperative learning model, namely: (1) increasing student thinking power; (2) providing thought time to enhance the quality of student responses; (3) students becoming more interested in thinking about topics in subjects; (4) students understand more about the subject matter concept; (5) Students can learn from other students, and (6) every student in their group has the opportunity to discuss or share their ideas.

Based on the above explanation and viewing the learning process in class VIII-a at SMP Negeri 24 OKU has not reached the stated KKM value, and the learning process uses the teaching method for learning activities and identifies the building blocks of the text of poetry, it is important to explore the ability of students to recognize the building blocks of the text of poetry through the use of the co-op text. The formula of the problem in this research is: "How to increase the ability to recognise the building blocks of poetry text by applying the think pair share the sort of cooperative learning model in class VIII-A students at SMP Negeri 24 OKU? The goal of this study is to explain an increase in the ability to recognize the building blocks of poetry text by applying the Cooperative Learning Model Think Pair to Class VIII-A students at SMP Negeri 24 OKU.

\section{METHODS}

This research is a class action research (classroom action research) which aims to explain an increase in the ability to recognize the building blocks of poetry text through the use of the think pair share style cooperative learning model for class VIII-A students at SMP Negeri 24 OKU.

This class action research protocol consists of three stages, with two meetings per cycle. The results of observations, assessments, field notes for each period are shown to assess the increase in the ability to recognize the building blocks of poetry text by applying the think pair share the form of cooperative learning model to students of class VIII-A at SMP Negeri 24 OKU.

The data obtained was analyzed using the methods of quantitative and qualitative analysis. Qualitative research is used to evaluate data from observations of shifts in behavior, student presence and involvement in teaching and learning activities performed through observation. In addition, quantitative analysis is used to assess student learning test scores. The intended result is to learn about the student's ability to recognize the building blocks of poetry text through the use of a think pair to share a cooperative learning model with class VIII-A students at SMP Negeri 24 OKU. 


\section{RESULTS AND DISCUSSION}

The findings of this analysis were analyzed qualitatively and quantitatively. Qualitative research is used to evaluate data from observations of shifts in behavior, student presence and involvement in teaching and learning activities performed through observation. In addition, quantitative analysis is used to assess student learning test scores. The intended result is to learn about the student's ability to recognize the building blocks of poetry text by the use of the think pair share a cooperative learning model in class VIII-A student at SMP Negeri 24 OKU.

In the implementation of the Cycle 1 action, the researcher is assisted by colleagues, i.e. teachers who teach Indonesian language learning, which aims to enhance students' ability to recognise the building blocks of poetry text through a think-pair sharing a cooperative learning model in class VIII-A students in SMP. Negeri 24 OKU by offering motivation for the learning material provided.

Results of student learning activities in student learning activity in the identification of building blocks of poetry text through the cooperative learning model think pair share in class VIII-A students at SMP Negeri 24 OKU in cycle 1 , it is understood that student learning activities are actively involved in the process. Learning as many as 11 or $44 \%$ of students, student learning results as many as 7 or $28 \%$ passively, and student learning experiences not involving as many as 7 or $28 \%$.

Based on the results of the study of the increase in the ability to recognize building blocks of poetry text through a cooperative learning model style think pair share in class VIII-A SMP Negeri 24 OKU in cycle 1 action, it turns out that students who achieved $44 \%$ mastery and scores achieved have not yet achieved completeness. The student's learning. In other words, the value obtained did not exceed the required KKM>70. Based on the results of the test data, the ability to recognize the building blocks of poetry text through the collaborative learning model of the think pair share form in class VIII-A student at SMP Negeri $24 \mathrm{OKU}$ in the first period of action was 2610 or an average of 64.40 . Students who reached completeness were 11 or $44 \%$ of students, respectively.

The phase of implementation in Cycle 2 is to follow up on the shortcomings in Cycle 1 where the effects of the action have not been changed and are not yet complete. The key activity carried out by students in Cycle 2 was to enhance learning by improving the ability to recognise the building blocks of poetry text through a think pair sharing a form of cooperative learning model in class VIII-A students at SMP Negeri 42 OKU.
Based on the results of observations of studentlearning behavior in the identification of the building blocks of poetry text through the cooperative learning model think pair share form in class VIII-A students at SMP Negeri 24 OKU in cycle 2 have not yet achieved the anticipated completeness. Students who absorbed the provided learning materials have not been able to recognize the building blocks of poetry text through a think-pair sharing the form of cooperative learning model.

This has an effect on student activity in the learning process. The involvement of students in the learning process in the second period of action was observed by peers, 17 students or $68 \%$ actively involved, 4 students or 16 per cent were not involved, 4 students or $16 \%$ were not involved. In addition, students were interested in recognizing the building blocks of poetry text through a cooperative learning model think pair sharing in class VIII-A students at SMP Negeri 24 OKU were observed by researchers themselves, 17 students were actively involved or $68 \%$ were passively involved. As many as 4 or 16 per cent of students and not as many as 4 or 16 per cent of students.

Based on the results of the test data, the ability to recognize the building blocks of poetry text through a cooperative think-pair learning model in Class VIII-a SMP Negeri 24 OKU in Cycle 2, corrected by peers, showed that the result was 1760 with an average of 70.40. Students who reached completeness were 17 or an overall completeness of 68 per cent. In addition, the results of the test data, corrected by the researcher himself, obtained 1,775 results with an average of 71 Students who reached completeness were 17 or an overall completeness of 68 per cent. Thus, the results of the research in Cycle 2 of the action can be said that the ability to recognize the building blocks of poetry text through the cooperative learning model think pair share form in Class VIII-A Students at SMP Negeri 24 OKU did not display an increase based on the KKM calculated to be $>70$ and completeness. Classically, $85 \%$ has not been reached, so it is appropriate to take the next step, namely Cycle 3.

The lack of ability to recognize the building blocks of poetry text through a think pair share the form of cooperative learning model for students of class VIII-A at SMP Negeri $24 \mathrm{OKU}$ is due to several factors in the "Girls Asking for Work Toto Sudarto Bachtiar" content, namely as follows: 1) students appear to pay less attention to the material presented, (2) The information discussed recognizes the building blocks of poetry texts that are not appealing to students, and students are more likely to pay attention to their poetry; (3) students who study in groups are more likely to learn independently; (4) students who are unable to cooperate with their friends; (5) Students are less able to improve their minds by recognizing the building blocks of poetry text. 
In the implementation of the Cycle 3 action, the researcher is assisted by colleagues, namely teachers who teach Indonesian language learning, which aims to see an increase in the ability to recognise the building blocks of poetry text through a think pair sharing a cooperative learning model in Class VIII-A students at SMP Negeri 24 OKU by providing inspiration for the learning material provided. The material taught in Cycle 3 is to define the building blocks of poetry text through the collaborative learning model think pair share form to students of Class VIII-a at SMP Negeri 24 OKU on the topic "Senja di Pelabuhan Kecil Kayar Chairil Anwar".

The consequence of studying student learning activities in student learning operation in the identification of building blocks of poetry text through the cooperative learning model think pair share in class VIII-A students at SMP Negeri 24 OKU in cycle 3, it is understood that student learning activities are actively engaged in the learning process of as many as 23 students or $92 \%$ of students. It is understood that the test data to increase the ability to recognise the building blocks of poetry text through the cooperative learning model think pair share in class VIII-A students at SMP Negeri 24 OKU in cycle 3 achieved a score of 1855 with an average score of 74.20. Students who complete KKM-based learning $(>70)$ are 23 with an average student completeness of $92 \%$. Thus, it can be assumed that Action Cycle 3 has met the KKM stipulation and is considered to be complete since, as a classical norm, $85 \%$ of the student's completeness has been fulfilled.

Some of the supporting factors are the enhanced ability to recognise the building blocks of poetry text through a think pair sharing a cooperative learning model in Class VIII-A at SMP Negeri 24 OKU in Cycle 3, including: (1) students can work with groups, (2) students can absorb the material well with the aid of their peers, (3) Students are able to build a way of thinking in order to consider the material provided by the teacher and the explanations offered by their peers, (4) students are able to solve current problems, (5) students are more secure in conveying ideas of thought while expressing opinions.

Related research confirms the analysis in this research, such as the research conducted by Muawiyah Research [9] in which the results of this study explain that the ability to recognize the building blocks of the text of poems that are read in Grade VIII students in an odd semester of SMP Negeri 1 Waytuba in the $2018 / 2019$ academic year can be said to be adequate because the average score is 6 In each aspect, it shows that the ability of the student to recognise the 57 theme elements is adequate, that the feeling aspect reaches an average score of 63 in the sufficient category, and that the tone/atmospheric aspect achieves an average score of 55 in the insufficient category, in terms of mandate, an average score of 66 was achieved in an appropriate group.

Another important study is Rosalinda's research [10] which concluded that out of 45 students who were research respondents, $21(46.67 \%)$ were able-bodied students and 24 (53.33 per cent) were still in the group. Identifying the building blocks of the text of poetry. Classically, the ability to recognise building blocks of poetry text for Grade 8 students of SMP Negeri Satap 10 Konawe Selatan is in the underprivileged category. It is claimed that, since the willingness of individual students to reach a minimum potential of 70 per cent is only $46.67 \%$, the classical completion requirements, namely $85 \%$, have not yet been met. Judging from the level of student competence, from the eight components which are aspects of the evaluation, namely the aspects of the theme, the mandate, the figure of expression, the rhythm, the word connotation, the symbolic words and the classical incomplete assessment, since the percentage does not meet the classification criterion of $85 \%$.

\section{CONCLUSION}

On the basis of the results of the study, it can be seen that there is an improvement in the ability to recognise the building blocks of poetry text through the cooperative learning model think pair share form in class VIII-A students at SMP Negeri 24 OKU in each cycle, it can be clarified that the results obtained in action cycle 1 are 1610 with an average of 64.40 . There were 11 students who completed the course with an average percentage of completeness of $44 \%$. There was an improvement in Cycle 2 where the findings reached a value of 1775 with an average of 71 per cent. Students who complete the course are 17 students with an overall percentage of completeness of 17 percent. Then the action cycle 3 increased again where the results obtained were 1855 with an average of 74,20. Students who complete up to 23 students with an overall percentage of completeness of $92 \%$.

\section{ACKNOWLEDGMENTS}

The author would like to thank Dr. H. Bukman Lian, M.M., M.Si., Chancellor of the PGRI Palembang University, Dr. Syaiful Eddy, M.Sc., Director of the Postgraduate Program at the PGRI Palembang University, Dr. Happy Fitria, M.Pd., Head of Education Management Study Program and all those who have helped morally and materially. May the goodness become multiple good deed.

\section{REFERENCES}

[1] Wardoyo, S. M. (2013). Teknik Menulis Puisi [Poetry Writing Techniques. Yogyakarta: Graha Science]. Yogyakarta: Graha Ilmu 
[2] Pradopo, R. J. (2012). Semiotika: teori, metode, dan penerapannya dalam pemaknaan sastra [Semiotics: theory, methods, and their application in literary meaning]. Jakarta: UMG. Press.

[3] Waluyo. (2015). Karya Sastra [Literary works]. Bandung: Qolbu

[4] Jabrohim. (2015). Kajian Puisi [Study of Poetry]. Jakarta: Rajawali Pers.

[5] Kosasih. 2013. Kajian Sastra [Literary works]. Jakarta: Rajawali Pers.

[6] Trianto. (2014). Model-Model Pembelajaran [Learning Models]. Jakarta: Rineka Cipta.

[7] Roestiyah, N. K. (2013). Strategi Belajar Mengajar [Teaching and Learning Strategies]. Jakarta: Rineka Cipta.

[8] Kasimmudin. (2017). Desain Pembelajaran Bermakna [Design of Meaningful Learning]. Bandung: Alfabeta.

[9] Muawiyah. (2019). Kemampuan Mengidentifikasi Unsur-Unsur Pembangun Puisi yang Dibaca Pada Siswa Kelas VIII Semester Ganjil SMP Negeri 1 Way Tuba Tahun Pelajaran 2018/2019 [The Ability to Identify Elements of Poetry Builder Read by Class VIII Students of Odd Semester SMP Negeri 1 Way Tuba Academic Year 2018/2019]. Jurnal BASTRA Volume 3 Nomor 2, Juni 2019. Halaman 206-233. http:jurnal-bastra-muawiyah.pdf

[10] Rosalinda, I. (2020). Kemampuan Mengidentifikasi Unsur-Unsur Pembangun Teks Puisi Siswa Kelas VIII SMP Negeri Satap 10 Konawe Selatan [The Ability to Identify Elements of Poetry Text Builder for Class VIII Students of SMP Negeri Satap 10 Konawe Selatan]. Jurnal BASTRA (Bahasa dan Sastra), Vol. 5 No.3, Edisi Juli 2020/e-ISSN: 25033875. http:jurnal-bastra-rosalinda.pdf 